\title{
Survey and assessment of vegetation in the CONECOFOR permanent plots
}

\author{
Bruno PETRICCIONE \\ Ministry for Agriculture and Forestry Policy, National Forest Service, Via Sallustiana 10, 00187 Roma, Italy \\ e-mail: b.petriccione@corpoforestale.it
}

\begin{abstract}
Phytosociological knowledge of plant communities and their synecological allocation are the reference basis of the CONECOFOR Programme. Vegetation surveys are performed in all the CONECOFOR plots (28), and have been performed in most of them for 6-7 years, following two fundamental approaches: (1) phytosociological (plant community level) and (2) dynamical (population level). According to a syntaxonomical analysis, 17 plant communities are represented in the CONECOFOR permanent plots, grouped in three classes (Querco-Fagetea, Vaccinio-Piceetea and Quercetea ilicis). Analysis of species richness at community level shows that the total number of vascular species varies between 14 and 81, the lowest values occurring in beech forests and the highest in Turkey oak forests; spruce forests are divided into two groups, the first comprising the secondary type (with high diversity values) and the second comprising the primary type (with relatively low diversity values). Analysis of the main dynamical tendencies show that fluctuation is the commonest ongoing process (occurring mostly in beech and primary spruce forests). Regeneration is also widespread, following the recent general decline of wood exploitation and coppicing, whereas regression and degeneration have been identified only in a few plots. The first vegetation changes seen during the first 6-7 years of investigation are slight and of very low significance. The temporal variation, however, is generally positive, with a fair increase in the number of species. Further assessment is required to evaluate the ongoing trends.
\end{abstract}

Key-words: vegetation, plant communities, permanent plots, syntaxonomy, species richness, dynamical tendencies

\section{INTRODUCTION}

Phytosociological knowledge of plant communities and their synecological allocation are the reference basis of the CONECOFOR Programme in its initial phase. The main objective of ground vegetation monitoring in the CONECOFOR permanent plots is to record changes due to natural dynamics and macro-disturbance factors (air pollution, climate change, etc.). The vegetation survey is performed in all the CONECOFOR plots (Tab. 1): 20 of them have been monitored since 1996/7, when the network was first established; 8 plots were added in 1999 or 2000, when the network was enlarged.

\section{MATERIAL AND METHODS}

Preliminary field surveys at community level were performed by the author, as part of the activities of the CONECOFOR National Focal Centre (Ministry for Agriculture and Forestry Policy - National Forest Service CONECOFOR Service), as well as syntaxonomical and synecological allocation of plant communities in all plots. The author also takes part annually in intercalibration exercises and in the subsequent repetition of measurements in certain plots. The Department of Botany and Ecology of the University of Camerino coordinates all the stages of the research, in particular the measurements performed by specialised personnel on all the plots; the Department supervises the harmonisation of the methods, the training and intercalibration of survey teams and local experts, applying quality control checks and implementing procedures to acquire, validate and store data, with a view also to making them available for subsequent integrated elaboration.

All plots are assessed every three years, and 11 plots annually, following two fundamental approaches (Canullo et al. 2001), according to EU Regulations no. 1091/1994 and no. 1545/1999 and the ICP Forests Manual (UN/ECE 1998): (1) phytosociological (plant community level) and (2) dynamical (population level). In the first approach the Braun-Blanquet data collection method (coverage scale for each species per layer) is applied to the analysis area and the large surrounding area, the former divided into 25 sample units of $100 \mathrm{~m}^{2}$. The second approach is based on 100 smaller sample units $\left(0.25 \mathrm{~m}^{2}\right)$, placed at random in the analysis area, where species coverage is studied more closely (functional individuals per species). A detailed map of plant populations (synusies) and functional individuals occurring in the analysis area will be drawn up every six years, to assess micro-changes in the plant coverage of each species (the first map, at 1:250 scale, was drawn in 1998).

According to the first approach, 25 sample units (12, in the routine survey) are marked out systematically in the inner grid of the fenced analysis area. Comparable replicates (12) are designated outside the fenced area within the buffer zone. A survey of forest systems with well-defined seasonality is performed in spring (14 plots). Measurements are made of the higher plants, ferns, bryophytes and epigean lichens. For the species nomenclature, see "Flora d'Italia" (Pignatti 1982),

Paper prepared within the CONECOFOR programme, by the contract with the Ministry for Agriculture and Forestry Policy - National Forest Service, Italy. CONECOFOR is part of the Pan-European Level II Intensive Monitoring of Forest Ecosystem and is co-sponsored by the European Commission. 
Tab. 1. Permanent plot list: ICP Forests, ICP Integrated Monitoring and National code, official name, altitude, mean annual temperature, mean annual precipitation, mean tree age (years), predominant tree species, survey years.

\begin{tabular}{|c|c|c|c|c|c|c|c|c|c|}
\hline ICPFor. & ICP IM & Nat. & Official name & $\begin{array}{l}\text { Altitude } \\
\text { (m a.s.l.) }\end{array}$ & $\begin{array}{l}\text { Mean temp. } \\
\left({ }^{\circ} \mathrm{C}\right)\end{array}$ & $\begin{array}{l}\text { Annual precipit. } \\
\qquad(\mathrm{mm})\end{array}$ & $\begin{array}{l}\text { Mean tree age } \\
(\mathrm{y})\end{array}$ & Dominant tree species & Survey years \\
\hline 01 & IT05 & ABR1 & Selva Piana & 1500 & 10,0 & 1300 & 110 & Fagus sylvatica & $1996 / 7-2002$ \\
\hline 02 & ---- & BAS1 & Monte Grosso & 1125 & 13,0 & 750 & 110 & Quercus cerris & 1996/7-1999 \\
\hline 03 & IT06 & CAL1 & Piano Limina & 1100 & 10,0 & 1500 & 110 & Fagus sylvatica & 1996/7-2002 \\
\hline 04 & ---- & CAM1 & Serra Nuda & 1175 & 10,0 & 1250 & 90 & Fagus sylvatica & 1996/7-2002 \\
\hline 05 & IT07 & EMI1 & Carrega & 200 & 12,0 & 1200 & 30 & Quercus petraea & $1996 / 7-2002$ \\
\hline 06 & IT08 & EMI2 & Brasimone & 975 & 10,0 & 1800 & 50 & Fagus sylvatica & 1996/7-1999 \\
\hline 07 & ----- & FRI1 & Bosco Boscat & 6 & 14,0 & 1500 & 30 & Carpinus betulus, $Q$. robur & 1996/7-2002 \\
\hline 08 & ---- & FRI2 & Tarvisio & 820 & 6,0 & 1500 & 70 & Picea abies & 1996/7-1999 \\
\hline 09 & IT09 & LAZ1 & Monte Rufeno & 690 & 12,0 & 1000 & 30 & Quercus cerris & 1996/7-2002 \\
\hline 10 & IT10 & LOM1 & Val Masino & 1190 & 8,0 & 1300 & 50 & Picea abies & 1996/7-2002 \\
\hline 11 & IT11 & MAR1 & Roti & 775 & 10,0 & 1250 & 50 & Quercus cerris & 1996/7-2002 \\
\hline 12 & ---- & PIE1 & Val Sessera & 1150 & 8,0 & 1500 & 70 & Fagus sylvatica & 1996/7-1999 \\
\hline 13 & ----- & PUG1 & Foresta Umbra & 800 & 12,0 & 800 & 50 & Fagus sylvatica & 1996/7-1999 \\
\hline 14 & ----- & SAR1 & Marganai & 700 & 14,0 & 900 & 110 & Quercus ilex & 1996/7-1999 \\
\hline 15 & ----- & SIC1 & Ficuzza & 940 & 13,0 & 800 & 30 & Quercus cerris & $1996 / 7$ \\
\hline 16 & IT12 & TOS1 & Colognole & 150 & 15,0 & 900 & 30 & Quercus ilex & 1996/7-2002 \\
\hline 17 & IT03 & TRE1 & Passo Lavazè & 1775 & 5,0 & 800 & 110 & Picea abies & 1996/7-1999 \\
\hline 18 & ---- & UMB1 & Pietralunga & 725 & 11,0 & 1250 & 50 & Quercus cerris & 1996/7-1999 \\
\hline 19 & IT13 & VAL1 & La Thuile & 1740 & 5,0 & 1000 & 70 & Picea abies & $1996 / 7-2002$ \\
\hline 20 & ----- & VEN1 & Pian di Cansiglio & 1100 & 5,0 & 1900 & 110 & Fagus sylvatica & 1996/7-2002 \\
\hline 21 & ----- & ABR2 & Rosello & 960 & 8,5 & 1000 & 130 & Abies alba, $Q$. cerris & 2002 \\
\hline 22 & ---- & LAZ2 & Monte Circeo & 190 & 15,5 & 900 & 30 & Quercus ilex & 2002 \\
\hline 23 & ----- & LOM2 & Giovetto & 1260 & 8,0 & 1350 & 70 & Picea abies & 2002 \\
\hline 24 & ---- & LOM3 & Valsassina & 1250 & 8,0 & 1500 & 50 & Fagus sylvatica & 2002 \\
\hline 25 & ----- & TOS2 & Cala Violina & 30 & 15,0 & 650 & 40 & Quercus ilex & 1999 \\
\hline 26 & ----- & TOS3 & Vallombrosa & 1170 & 10,0 & 1300 & 130 & Fagus sylvatica & 1999 \\
\hline 27 & IT01 & BOL1 & Renon & 1740 & 4,0 & 970 & 110 & Picea abies & 2002 \\
\hline 28 & ----- & LIG1 & Monte Zatta & 1290 & 10,0 & 1800 & 110 & Fagus sylvatica & 2002 \\
\hline
\end{tabular}

"Mosses of Europe and Azores" (Corley et al. 1981, 1991), and for the lichens, local florae. Codified lists of European reference are also being prepared, based on Flora Europaea (Tutin et al. 1964-1980) and "Moosund Farnpflanzen Europas" (Frey et al. 1995). Measurements are performed following the phytosociological method of Braun-Blanquet (1932, 1964), based on the visual estimate of cover by percentage intervals, with indexes assigned to each species $(\mathrm{r}=$ rare; $+=<1 \% ; 1=$ $1-5 \% ; 2=5-25 \% ; 3=25-50 \% ; 4=50-75 \% ; 5=75-$ $100 \%)$. The vertical layers considered are: trees, shrubs, herbs and mosses. Syntaxonomical nomenclature is according to Pignatti (1998) and follows the International Association for Vegetation Science Code (Barkman et al. 1986; Weber et al. 2000).

The second approach involves systematically marking out 100 sampling units inside an ideal grid in the fenced analysis plot, comprising the vegetation layer below $1.3 \mathrm{~m}$. The cover of each species is estimated in $\mathrm{cm}^{2}$, mean height is measured, the individuals present are counted according to various typologies and any damage recorded; in ligneous species these elements are measured individually.

A detailed mapping (scale 1:250) of the dominant species and synusies in the same layer over the whole fenced study area $\left(50 \times 50 \mathrm{~m}^{2}\right)$ is also envisaged.

To standardise the methods used by the survey teams, especially during the phase of data measurement in the field, a handbook has been written (Manuale
Nazionale di Riferimento, Canullo et al. 1999), defining procedural and technical standards; in addition, annual intercalibration and training exercises are organised for survey personnel. Controls to assess the quality of the measurements are also performed annually by the Department of Botany and Ecology of the University of Camerino.

Dynamical tendencies in the vegetation (fluctuation, regeneration, degeneration and regression, according to Falinski 1986, 1989) have been identified on the basis of species composition and, secondarily, vertical structure. A check-list of indicator species of dynamical processes has been used (Petriccione \& Claroni 1996), as well as the few papers describing forest vegetation in Italy (among them, Pedrotti \& Falinski 1990, 1991; Canullo \& Pedrotti 1993).

\section{RESULTS}

The plant communities represented in the CONECOFOR permanent plots are described systematically and syntaxonomically. The 28 areas considered include 17 different vegetal associations, grouped in three classes (Tabs 2, 3).

The best represented class, with a total of 17 areas, is that of deciduous broadleaf European forests (Querco-Fagetea), divided into two different orders.

1) Thermophilous oak forests (Quercetalia pubescentis): these include all Quercus cerris forests, divided 
Tab. 2. Systematical and syntaxonomical outline of plant communities represented in the CONECOFOR permanent plots (National codes on side).

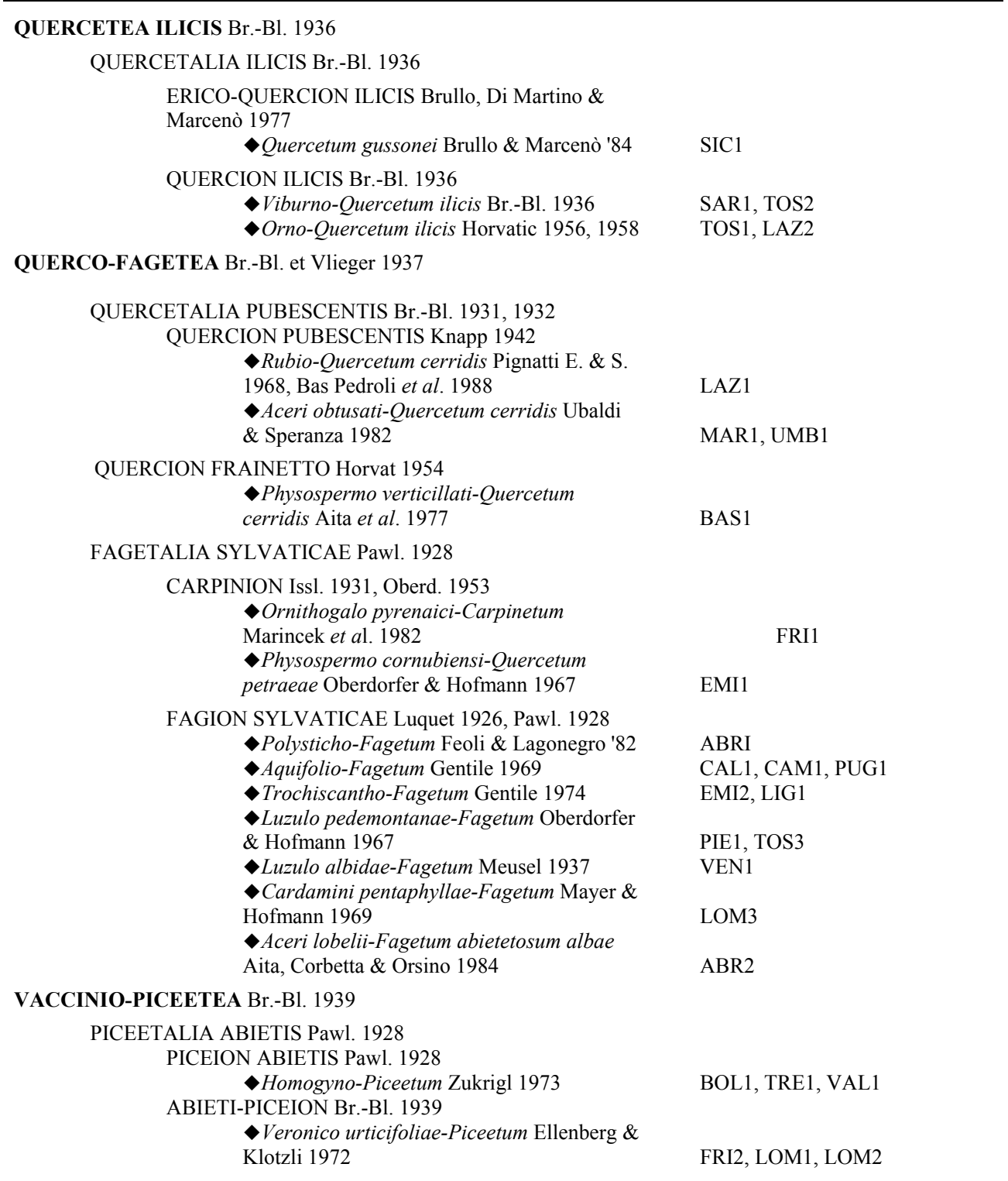

into three associations (note that the areas MAR1 and UMB1 belong to the same entity, while the Turkey oak forest of BAS1 is quite distinct from the other areas of Central Italy, being located in an autonomous alliance).

2) Mesophilous oak and beech forests (Fagetalia sylvaticae): these include Quercus robur and $Q$. petraea acidophilous forests (of the Carpinion alliance) and beech forests (of the Fagion sylvaticae alliance); the last of these present a great variety, as they are divided into 7 associations, according to latitude, climate and type of substrate. All the areas in southern Italy (CAL1, CAM1 and PUG1) belong to the same entity, the most thermophilous of all the entities. Those of the northern Apennines (EMI2,
LIG1 and TOS3) are divided into two associations, one neutrophilous and the other acidophilous. The Alpine beech forests (LOM3, PIE1 and VEN1) are divided into three different associations with differences in their ecological and biogeographical significance; the beech forest situated at the highest altitude is that of area ABR1, in the internal Central Apennines, ascribed to a particularly microthermal autonomous association. In the same geographical area, but in a more southerly position and on the eastern Adriatic slope, is area ABR2, which is a case apart, in so far as it is a forest in which beech is completely absent, with marked co-dominance of Abies alba, Quercus cerris, Carpinus betulus, Acer lobelii and Acer campestre, in direct contact with 
Tab. 3. Permanent plot list: ICP Forests, ICP Integrated Monitoring and National code, syntaxon, total number of vascular species (first survey year), number of species occurring in tree layer (first survey year), main dynamical tendency.

\begin{tabular}{|c|c|c|c|c|c|c|}
\hline ICP For & $\mathrm{IM}$ & Nat. & Syntaxon & $\begin{array}{l}\text { Vascular } \\
\text { species } N^{\circ}\end{array}$ & $\begin{array}{l}\text { Tree layer } \\
\text { species } N^{\circ}\end{array}$ & $\begin{array}{l}\text { Main dynamical } \\
\text { tendency }\end{array}$ \\
\hline 15 & ----- & SIC1 & Quercetum gussonei & 81 & 1 & regression \\
\hline 14 & ----- & SAR1 & Viburno-Quercetum ilicis & 38 & 5 & regression \\
\hline 25 & ----- & TOS2 & " & 20 & 5 & fluctuation \\
\hline 16 & IT12 & TOS1 & Orno-Quercetum ilicis & 44 & 15 & regression \\
\hline 22 & ----- & LAZ2 & $"$ & 29 & 6 & regeneration \\
\hline 09 & IT09 & LAZ1 & Rubio-Quercetum cerridis & 53 & 1 & degeneration \\
\hline 11 & IT11 & MAR1 & Aceri obtusati-Quercetum cerridis & 69 & 4 & regeneration \\
\hline 18 & ----- & UMB1 & " & 55 & 4 & regression \\
\hline 02 & ----- & BAS1 & Physospermo-Quercetum cerridis & 72 & 2 & degeneration \\
\hline 07 & ----- & FRI1 & Ornithogalo pyrenaici-Carpinetum & 43 & 6 & regeneration \\
\hline 05 & IT07 & EMI1 & Physospermo-Quercetum petraeae & 30 & 6 & regeneration (fluctuation) \\
\hline 01 & IT05 & ABR1 & Polysticho-Fagetum & 22 & 1 & regeneration \\
\hline 03 & IT06 & CAL1 & Aquifolio-Fagetum & 34 & 3 & fluctuation (regeneration) \\
\hline 04 & ----- & CAM1 & $"$ & 31 & 2 & fluctuation \\
\hline 13 & ----- & PUG1 & $"$ & 29 & 7 & fluctuation (regeneration) \\
\hline 06 & IT08 & EMI2 & Trochiscantho-Fagetum & 26 & 3 & regeneration \\
\hline 28 & ----- & LIG1 & $"$ & 24 & 2 & fluctuation \\
\hline 12 & ----- & PIE1 & Luzulo pedemontanae-Fagetum & 17 & 2 & flictuation \\
\hline 26 & ----- & TOS3 & $"$ & 14 & 1 & fluctuation \\
\hline 20 & ----- & VEN1 & Luzulo albidae-Fagetum & 42 & 1 & fluctuation \\
\hline 24 & ----- & LOM3 & Cardamini pentaphyllae-Fagetum & 28 & 3 & fluctuation \\
\hline 21 & ---- & ABR2 & Aceri lobelii-Fagetum abietetosum & 66 & 12 & fluctuation \\
\hline 17 & IT03 & TRE1 & Homogyno-Piceetum & 14 & 2 & fluctuation \\
\hline 19 & IT13 & VAL1 & $"$ & 39 & 4 & fluctuation \\
\hline 27 & IT01 & BOL1 & $"$ & 54 & 5 & regression \\
\hline 08 & ----- & FRI2 & Veronico uticifoliae-Piceetum & 59 & 5 & regeneration \\
\hline 10 & IT10 & LOM1 & $"$ & 56 & 14 & regeneration (fluctuation) \\
\hline 23 & ----- & LOM2 & $"$ & 34 & 3 & regeneration \\
\hline
\end{tabular}

communities dominated by Fagus sylvatica and Abies alba, the composition and structure of which are linked to optimal local edaphic and climatic conditions.

The second most represented class (6 areas) includes the boreal coniferous forests (Vaccinio-Piceetea), divided into only two associations (both of the order Piceetalia abietis and each belonging to a different alliance), according to the altitude: the mountain spruce forests, replacing the original beech forests, are represented in areas FRI2, LOM1 and LOM2, while the subalpine spruce forests are found in the network's areas of maximum altitude (BOL1, TRE1 and VAL1).

The last class (5 areas) includes the evergreen Mediterranean forests (Quercetea ilicis), divided into two alliances (of the same Quercetea ilicis order ): the endemic alliance Erico-Quercion ilicis includes an endemic association of Sicily, represented in area SIC1 by a Quercus cerris forest (deciduous) in a very distinctive morphological and ecological form, which some authors have elevated to the rank of subspecies or even to that of an autonomous species, Quercus gussonei (Borzi) Brullo; the other alliance (Quercion ilicis) includes the other two associations, one more thermophilous (areas SAR1 and TOS2) and the other more mesophilous (LAZ2 and TOS1).

The detailed maps produced in 1998 (Canullo et al. 2001) were a useful contribution towards defining the initial state of the system. Digitalisation and the fact that data can be processed using GIS techniques, together with the referenciation of the measurement grid at phytocenosis and population level, offer an excellent chance that in future we will be able to visualise medium scale changes in the study areas.

A preliminary analysis of species richness at community level, on the basis of the first survey year (the only one with fully comparable data), reveals some interesting points (Tab. 3; data refer to all vascular plants on 25 sample units, on a total relevé surface of 2500 $\left.\mathrm{m}^{2}\right)$.

1) The total number of vascular species varies between 14 and 81, with the lowest values in plots with Fagus sylvatica-dominated forests and the highest in Quercus cerris-dominated plots (plot ABR2 is in a very high diversity situation, due to its peculiar status, explained above).

2) Picea abies-dominated plots are divided into two groups, the first including secondary spruce forests (FRI2 and LOM1), with high diversity values, and the second including primary spruce forests (TRE1, VAL1), with relatively low diversity values (plot BOL1 is in a situation of high diversity, due to a major ongoing regression process).

3) Quercus ilex-dominated plots show a wide range of degrees of diversity, with low values in forests in which fluctuation and regeneration are dominant 
processes, and medium values where regression is the main tendency (SAR1, TOS1).

4) The number of species occurring in the tree layer varies between 1 and 15, with the lowest value in Fagus sylvatica-dominated plots and the highest in the plots characterised by marked ecological transitions (Central-European vs Subatlantic belt: ABR2; Subatlantic vs Boreal belt: LOM1; Mediterranean vs. Central-European belt: TOS1).

According to a preliminary analysis of the main dynamical tendencies, the plots are divided into four groups (Tab. 3).

1) Fluctuation is the predominant ongoing process in Fagus sylvatica and primary Picea abies-dominated forests (12 plots, including the special case of ABR2 and the Quercus ilex-dominated forest of TOS2).

2) Regeneration is the predominant ongoing process, following the recent decline of wood exploitation and coppice management, in secondary Picea abies, Quercus cerris and some Fagus sylvatica-dominated forests (9 plots, including the Quercus ilexdominated forest of LAZ2).

3) Regression is the predominant ongoing process in some Quercus cerris- and Quercus ilex-dominated forests (5 plots); the main indicator species are Rubus ulmifolius, Urtica dioica, Pteridium aquilinum and Cytisus villosus.

4) Degeneration is the predominant ongoing process in some Quercus cerris-dominated forests (2 plots); the main indicator species are Geranium robertianum, Geum urbanum, Galium aparine, Cruciata glabra and Cirsium arvense.

Fluctuation occurs in plots with a low number of species $(<30$, except for the special case of ABR2), whereas regression and degeneration processes occur in plots with high diversity (total no. of species $>40$ in the first case and between 50 and $70 \mathrm{ca}$ in the second one).

The first changes in vegetation observed in the initial phase of the survey, from 1996/7 to 1999 (19 plots) and from 1996/7 to 2002 (11 plots), were slight and of very low significance. During the first 2-3 years of the survey (Campetella \& Canullo 1999), the total number of species, in some plots, showed a fairly marked variation, largely because bryophytes and lichens were also included in the assessment in the last year, but also due, albeit to a lesser degree, to an improvement in the identification of the collected taxa. The temporal variation, however, is generally positive. The results for 11 plots (6-7 years) show a similar increase in the total number of species in all except LOM1 and TOS1, where there was a slight decrease. Only in the case of Quercus cerris-dominated plots (BAS1, MAR1, LAZ1 and UMB1) does the increase reach significant values ( $c a$ 10-20 species).

However, in no case did we observe the permanent disappearance of species previously recorded. To evalu- ate the kind of trends in progress it would be essential to be in possession of longer time series, of at least 10-20 years; significant changes (including the disappearance of many species) have been recorded, e.g. in Swiss beech and oak forests, on the basis of 30-50 years of observations (Walther 1997; Walther \& Grundmann 2001). It will in any case be necessary to analyse the qualitative variations in the species composition, highlighting any temporal changes in the presence, frequency and cover of certain key species chosen as indicators of ongoing processes (e.g. nitrophilous, thermophilous, etc. species).

\section{CONCLUSIONS}

A systematic and syntaxonomical profile of plant communities represented in the CONECOFOR permanent plots shows that the 28 studied plots include 17 plant communities, grouped in three classes. The best represented class includes the Central-European broadleaved deciduous forests (Querco-Fagetea); the second includes the Boreal coniferous forests (VaccinioPiceetea), with the least represented including the Mediterranean evergreen forests (Quercetea ilicis).

A preliminary analysis of species richness at community level reveals that the lowest values occur in beech forests and the highest in Turkey oak forests, whereas spruce forests are divided into two groups, the first including the secondary type (with high diversity values) and the second including the primary type (with relatively low diversity values).

According to a preliminary analysis of the main dynamical tendencies, fluctuation is the commonest ongoing process (occurring mostly in beech and primary spruce forests). Regeneration is also widespread, following the recent general abandonment of wood exploitation and coppice management (occurring mostly in Turkey oak and secondary spruce forests). Regression is recorded in a few plots, becoming predominant in some Quercus cerris- and Quercus ilex-dominated forests, whereas degeneration is predominant only in two Quercus cerris-dominated plots.

The first vegetation changes identified during the initial 6-7 years of investigation are slight and of very low significance. The temporal variation, however, is generally positive, with a fair increase in the number of species. Further assessment is required to evaluate ongoing trends: significant changes (including the disappearance of many species) have been recorded, e.g. in Switzerland, on the basis of 30-50 years of observations (Walther 1997; Walther \& Grundmann 2001).

\section{REFERENCES}

Barkman, J.J., J. Moravec \& S. Rauschert. 1986. Code of phytosociological nomenclature, $2^{\text {nd }}$ Ed. Vegetatio, 67(3): 145-195.

Braun-Blanquet, J. 1932, Plant Sociology. New York.

Braun-Blanquet, J. 1964. Pflanzensoziologie. Grundzuge der Vegetationskunde. Springer. Wien-New York. 
Campetella, G. \& R. Canullo. 1999. Plant biodiversity as an indicator of the biological status in forest ecosystems: community and population level. In: Ferretti M. (Ed.), Integrated and Combined $(I \& C)$ Evaluation of Intensive Monitoring of Forests Ecosystems in Italy. Concepts, Methods and First Results. Ann. Ist. Sperim. Selvicoltura (Arezzo), 30: 73-79.

Canullo R. \& F. Pedrotti. 1993. The cartographic representation of the dynamical tendencies in the vegetation: a case study from the Abruzzo National Park, Italy. Oecologia Montana, 2: 13-18.

Canullo, R., G. Campetella \& M.-C. Allegrini. 2001. Studio della vegetazione. In: Allavena S., Isopi R., Petriccione B. \& Pompei E. (Eds), Programma Nazionale Integrato per il Controllo degli Ecosistemi Forestali. Secondo rapporto, 2000. Ministero delle Politiche Agricole e Forestali. Roma.

Canullo, R., M.-C. Allegrini, G. Nicoletti, G. Campetella, S. Allavena, R. Isopi, B. Petriccione, \& E. Pompei. 1999. Analisi della vegetazione nelle aree permanenti della Rete Nazionale Integrata CONECOFOR. 1999/2000. Manuale Nazionale di Riferimento per il coordinamento, i rilevatori ed $\mathrm{i}$ responsabili di zona. Università degli Studi di Camerino.

Corley, M.F.V., A.C. Crundwell, M.O. Mull \& A.J.E. Smith. 1981. Mosses of Europe and the Azores; an annotated list of species, with synonyms from recent literature. J. Briol., 11: 609-689.

Corley, M.F.V. \& A.C. Crundwell. 1991. Additions and amendments to the mosses of Europe and the Azores. $J$. Briol., 16: 337-356.

Falinsky, J.B. 1986. Vegetation dynamics in temperate lowland primeval forest. Ecological studies in Bialowieza forest. Geobotany, 8: 1-537.
Falinsky, J.B. 1989. Le temp et l'éspace dans les recherches écologiques sur le dynamisme de la végétation. Giorn. Bot. Ital., 123: 81-107.

Falinsky, J.B. \& F. Pedrotti. 1990. The vegetation and dynamical tendencies in the vegetation of Bosco Quarto, Promontorio del Gargano, Italy. Braun-Blanquetia, 5: 1-31.

Falinsky, J.B. \& F. Pedrotti. 1991. The vegetation and dynamical tendencies in the vegetation: the example of Bosco Quarto in the Promontorio del Gargano (Italy). Phytocoenosis, 3: 65-70.

Frey, W., J.-P. Frahm, E. Fischer \& W. Lobin. 1995. Die Moos- und Farnpflanzen Europas. In: Kleine Kryptogamenflora. IV. $6^{\text {th }}$ Ed. Gustav Fischer Verlag. StuttgartJena-New York.

Petriccione, B. \& N. Claroni. 1996. The dynamical tendencies in the vegetation of Velino Massif (Abruzzo, Italy). Doc. Phyt., 16: 365-373.

Pignatti, S. 1982. Flora d'Italia. 1-3. Edagricole. Bologna.

Pignatti, S. 1998. I boschi d'Italia. UTET. Torino.

Tutin, T.G., V.H. Heywood, N.A. Burges, D.N. Moore, D.H. Valentine, S.M. Walters \& D.A. Webb. 1964-1980. Flora Europaea, 1-5. Cambridge University Press.

UN/ECE. 1998. Convention on Long-range Transboundary Air Pollution. International Co-operative Programme on Assessment and Monitoring of Air Pollution Effects on Forests. Manual on methods and criteria for harmonised sampling, assessment, monitoring and analysis of the effects of air pollution on forests. BFH. Hamburg.

Walther, G.-R. 1997. Long-term changes in species composition of Swiss beech forests. Ann. Bot., 55: 77-84.

Walther, G.-R. \& A. Grundmann. 2001. Trends of vegetation change in colline and submontane climax forests in Switzerland. Bull. Geobot. Inst. ETH, 67: 3-12.

Weber, E.F., J. Moravec \& J.-P. Theurillat. 2000. Code of Phytosociological nomenclature. J. Veg. Sci., 11: 739-768. 